\title{
Undervisningsevaluering og udvikling af underviserkompetencer
}

Rikke von Müllen, cand.mag. i retorik, peedagogisk konsulent, Samfundsvidenskabeligt Fakultet, Københavns Universitet.

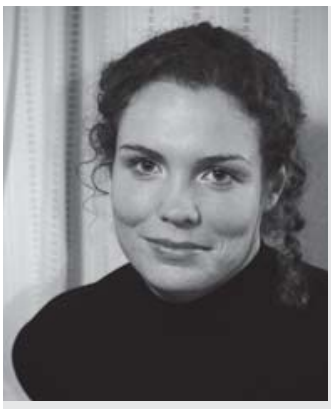

Rikke von Müllen er pædagogisk konsulent på Pædagogisk Center Samfundsvidenskab ved Københavns Universitet. Der holder hun bl.a. pædagogiske kurser for underviserne og kurser og vejledning i opgaveskrivning, argumentation, almen studieteknik og lign. for de studerende. Hun skrev i 2004-05 speciale om undervisningsevaluering på Københavns Universitet.

Konklusionen på denne artikel er, at kriteriebaseret og deltagerbaseret evaluering er interessante alternativer til de forskellige former for tilfredshedsevaluering, når fokus er på udvikling af underviserkompetencer. Formerne har hver deres styrker og svagheder, men kan begge vare med til at sikre, at kvaliteten af data fra studenterevalueringer bliver højere, og at underviserne ikke foler sig domt af ukvalificerede.

\section{Fokus på underviseren}

Systematik, sammenlignelighed og offentliggørelse af universiteternes undervisningsevaluering får megen opmærksomhed fra regering, globaliseringsråd og ny ledelse ${ }^{1}$. Det medfører krav om, at evaluering skal standardiseres, kvantificeres og net-baseres. Det er afgjort en vigtig diskussion, hvilke fordele og ulemper der kan være ved disse målsætninger. Umiddelbart kan man håbe, at den store opmærksomhed på det universitetspædagogiske område, vi i øjeblikket oplever både internt på universiteterne og $i$ den offentlige og politiske debat, vil være med til at skabe store og langsigtede ændringer til det bedre. Men dette globale fokus for evaluering tilbyder ikke meget til den enkelte, som ønsker at blive en bedre underviser, og kigger efter hjælp i evalueringen af sin undervisning.

Hvis man ønsker at bruge undervisningsevaluering til udvikling af undervisernes undervisningskompe- tencer, er det vigtigt, at man ikke glemmer det lokale niveau, hvor redskaber til kompetenceudvikling bliver konkrete og individuelt tilpassede, og hvor man kan handle hurtigere.

Jeg vil i denne artikel koncentrere mig om evaluering på det lokale niveau med fokus på pædagogisk udvikling af den enkelte underviser.

\section{Materiale}

I bestræbelsen på at få indsigt i skriftlige studenterevalueringers mulige nytte $i$ forhold til underviseres kompetenceudvikling gennemførte jeg i efteråret 2004 en retorisk analyse og kritik af 33 evalueringsskemaer eller-systemer til studenterevaluering af undervisning fra 20 fag på Københavns Universitets (herefter KU) seks fakulteter som datamateriale til mit speciale i retorik: Undervisningsevaluering som redskab til padagogisk udvikling på KU. Alle fag, jeg henviser til her i artiklen, udbydes af institutter eller afdelinger på KU.

\section{Hvad skal evalueres og hvordan?}

At evaluere undervisning kan betyde brug af metoder så forskellige som, at underviseren taler med sine elever over kollega- eller ledelsessupervision til statistisk gennemarbejdning af eksamensresultater; men på KU betyder undervisningsevaluering i praksis meget ofte studenterevaluering, dvs. variationer over en skabelon, hvor de studerende systematisk og næsten altid skriftligt udspørges om deres opfattelse af undervisning eller i sjældnere tilfælde hele uddannelsen. Min påstand er, at selv uden at tage fundamentalt anderledes evalueringsformer i brug kunne undervisningsevaluering, $i$ højere grad end tilfældet er i dag, være et redskab til kompetenceudvikling for undervisere.

Helt fundamentalt for, at undervisningsevaluering kan bruges til kompetenceudvikling, er, at vi bevæger os væk fra at evaluere de studerendes umiddelbare tilfredshed, så de studerende ikke skal være undervisningens subjektive dommere. Det er nødvendigt ikke 
bare for at få den bedst mulige kvalitet af de data, vi vurderer behovet for kompetenceudvikling ud fra, men også fordi underviserne er nødt til at være aktive, positive medspillere $i$ en kompetenceudviklingsproces, og det bliver de aldrig så længe, de starter med at føle sig bedømt af ukvalificerede dommere. Selv undervisere, som de studerende er meget tilfredse med, kan føle, at rosen ikke er troværdig.

Jeg vil i denne artikel pege på to mulige alternativer, hvis vi fortsat vil have, at de studerende skal være de primære evaluatorer.

Enten kan de studerende kvalificeres som dommere og lave kriteriebaseret evaluering. Eller også kan de studerende alene beskrive undervisningen og deres oplevelser i og af den; værdisættelsen af de studerendes oplevelser i undervisningen skal så ikke ligge hos dem. Sidstnævnte kalder jeg deltagerbaseret evaluering.

\section{Kriteriebaseret undervisningsevaluering}

Kriteriebaseret evaluering sker udfra kriterier eller idealer. Man ved, hvordan det burde være på forskellige områder, og evaluerer i hvilken grad, det faktisk er sådan. Men ved de studerende, hvordan undervisning burde være?

Mange undervisere har en idé om, at studerende ikke ved, hvad der er godt for dem selv, og det er da egentlig også urimeligt at forvente, at i hvert fald uerfarne universitetsstuderende umiddelbart skal kende - og have et reflekteret forhold til - kriterier for god undervisning, der er så svære at sætte på formel, at selv underviserne mange steder vægrer sig ved at tage hul på diskussionen. Men erfarne studerende kunne man måske forvente ville have en bedre fornemmelse for deres egen læring; der er antageligt en vigtig distinktion mellem, hvad vi med Dreyfus \& Dreyfus (1999) kunne kalde novicer og eksperter, blandt de studerende som evaluatorer. Det er en pointe, der i høj grad overses, når man indfører standardevalueringer for alle studerende på alle niveauer, at der er forskel på, hvad man med rimelighed kan forvente, at en 19-årig førsteårsstuderende kontra en 5.-års pædagogikstuderende har en reflekteret mening om ${ }^{4}$. Når man på psykologi starter evalueringen af holdundervisning med at spørge til, hvorvidt undervisningen "indgår relevant i studiets sammenhæng«, "har relevant indhold (pensum)« og "er tilstrækkeligt rettet mod at forberede eksamen«, er min tillid til en forsteårsstuderendes svar begrænset.

Den slags overbliksspørgsmål vil erfarne studerende naturligvis bedre kunne svare på, men når det kommer til forståelsen af, at god undervisning ikke er lig med undervisning, man som studerende får det rart af, er der kun forskel på erfarne og uerfarne studerende for så vidt, som studiet og herunder evalueringsformen åbner deres øjne. Evaluerer man år efter år tilfredshed og lader disse evalueringer få konsekvenser for genansættelser mv., kan man tværtimod opdrage de studerende til, at deres tilfredshed eller velbehag er kriteriet for god undervisning; og så vil det være tilfredshed/velbehag, der kommenteres, selv hvis man begynder at spørge til noget andet.

God undervisning er som tommelfingerregel aktiverende undervisning (f.eks. Herskin, 2001). Kun i en sådan aktiveres de studerendes egne læreprocesser, men at lære er også på universitetsniveau en frustrerende proces (Berliner \& Bertelsen, 1989), der kan kræve aflæring ${ }^{5}$ og ikke mindst hårdt arbejde, og kun meget reflekterede studerende vil gennemskue og acceptere denne frustration.

Peter Dahler-Larsen (2004a) argumenterer for, at evaluering af tilfredshed kun viser, i hvor høj grad undervisningen levede op til de studerendes forventninger; og både forventet udbytte og oplevet udbytte er faktorer, der er:

"(..) stærkt påvirkelige af forskellige psykologiske forhold, som ikke altid er relevante for en egentlig kvalitetsvurdering af undervisningen«. »(...) hvis man sigter efter at gøre de studerende tilfreds, så vil man overse, hvad de faktisk har behov for at lære.« (s. 24-25. Se også Dahler-Larsen, 1997, s. 223-225).

Rienecker og Jørgensen (1999, s. 58-59) refererer en undersøgelse, der viser, at studerende foretrækker skrivekurser, hvor de mest skal høre efter, frem for kurser, hvor de selv skal arbejde aktivt.

Aktiverende og effektiv undervisning kan altså medfore negative tilfredshedsevalueringer fra de studerende ${ }^{6}$ - men man skal selvfølgelig være opmærksom på, at kausalitetspilen ikke går den modsatte vej; negative evalueringer er selvfølgelig ikke oftest tegn på god undervisning.

Hvis vi vil bruge de studerende som bedømmere af undervisningens kvalitet, må de tidligt sættes ind i, hvad kriterierne for god undervisning er.Vi må, hvis vi skal tage princippet helt alvorligt, undervise dem i basal læringsteori og illustrere og italesætte, at det kræver aktiv deltagelse og frustration at komme til at beherske fagligt stof, så de kan blive selvrefleksive og kvalificerede til at se deres egen læreproces mere objektivt.

Det er et udmærket og relevant mål på uddannelser som pædagogik, psykologi og retorik, men på mange andre fag vil man nok regne det for at være for tidskrævende i forhold til relevansen af udbyttet, så kan man i stedet overveje deltagerbaseret evaluering.

Pragmatisk set kan mindre end direkte undervisning i kriterierne måske også gøre det, men kriteriebaseret evaluering kræver i hvert fald som absolut minimum, at kriterierne ekspliciteres for de studerende og indgår som en del af evalueringen, der så består i at afgøre, i hvor høj grad undervisningen har levet op til disse kriterier. 


\section{Kriteriebaserede evalueringer på KU}

Hvis man vil have de studerende til at evaluere $i$ forhold til præcise kriterier, må de optrykkes direkte i evalueringen til hjælp for hukommelsen ${ }^{7}$. Et spørgsmål i litteraturvidenskabs standardskema til slutevaluering lyder:»Hvordan synes du kurset lever op til målsætninger og kursusbeskrivelse? « Men disse er ikke gengivet, så de studerende, der ikke kan deres studieordning udenad, făr ikke megen hjælp. Præcis det samme er tilfældet i Kemisk Instituts og Biologisk Instituts skemaer.

På de medicinske institutter har man også det kriteriebaserede ideal, men her er kriterierne i langt højere grad arbejdet ind i selve evalueringerne. Der laves målbeskrivelser for alt - i nogle fag helt ned til formål med den enkelte forelæsning, der så også evalueres separat. Evalueringsskemaerne indeholder disse målbeskrivelser og desuden en skala for, i hvor høj grad formålet er opfyldt, som de studerende skal placere undervisningen på. Nogle spørgsmål har 15 liniers målbeskrivelser, hvilket giver sine egne metodiske problemer, men et kort eksempel er: "Hensigten med øvelserne/demonstrationerne er, at de skal konkretisere teorien. Gjorde de det?« Der skal så svares på en syvtrinskala fra »Slet ikke" til "I optimalt omfang". Der er tale om klare kriterier, der ikke handler om individuel tilfredshed. Men det er nok ikke alle uddannelser, der vil finde det meningsfyldt at målbeskrive med en detaljeringsgrad, der gør det muligt at evaluere alt alene ud fra målbe- skrivelser - selvom det sikkert kunne være en nyttig øvelse at forsøge at se, hvor langt man faktisk kunne komme.

Hvis vi leder efter mere generelle kriterier at evaluere ud fra, er Institut for Psykologis skema måske det mest interessante blandt de indsamlede eksempler fra KU. Her nærmer man sig nogle bud på, hvad god undervisning er, som ikke er afhængige af den konkrete studieordning. Kriterierne stilles op som udsagn, der beskriver undervisningen, og som respondenterne skal angive en grad af enighed i på en femtrinskala. Mange af underpunkterne findes også rundt omkring $i$ andre fags evalueringer, men formen med overordnede udsagn med fed skrift, der klart angiver, hvad der er kvalitetskriteriet, og underpunkterne, der angiver, hvordan det skal give sig konkret udtryk i undervisningen, er en usædvanligt klar markering af, hvad der regnes for positivt på faget.

Som i utallige andre skemaer spørges der også her til de studerendes indsats og fremmøde, men det, at det gøres under overskrifter, der angiver, at det egentlig handler om kvalificering af undervisningen og om samarbejdsklimaet, giver en anden kontekst. Man spørges om sin indsats, fordi det naturligvis påvirker undervisningens niveau, ikke for at man skal føle skyld eller selvretfærdighed, som man kan få mistanke om vil blive resultatet, når man svarer på spørgsmålet fra Økonomisk Instituts standardskema i fig. 2.

\begin{tabular}{|c|c|c|c|c|c|}
\hline 3. Undervisningens deltagere har medindflydelse, dvs.: & $\begin{array}{l}\text { Meget } \\
\text { enig }\end{array}$ & Enig & Neutral & Uenig & $\begin{array}{l}\text { Meget } \\
\text { uenig }\end{array}$ \\
\hline \multicolumn{6}{|l|}{ planer og beslutninger er velbegrundede } \\
\hline \multicolumn{6}{|l|}{ deltagernes refleksion / diskussion af undervisning og læring befordres } \\
\hline \multicolumn{6}{|l|}{ der følges op på ovennævnte refleksioner / diskussioner i praksis } \\
\hline der er rimelig fordeling mellem lærerstyring og studenteraktivitet & & & & & \\
\hline
\end{tabular}

Fig. I: Spørgsmål 3 og 5 i psykologis standardskema (2004)

\begin{tabular}{|l|l|l|l|l|l|}
\hline 5. Undervisningen foregår i et rimeligt samarbejdsklima, dvs.: & $\begin{array}{l}\text { Meget } \\
\text { enig }\end{array}$ & Enig & Neutral & $\begin{array}{l}\text { Uenig } \\
\text { der er respekt mellem deltagerne som kompetente, voksne } \\
\text { mennesker }\end{array}$ & $\begin{array}{l}\text { Meget } \\
\text { uenig }\end{array}$ \\
\hline lærerne overholder mødetider og andre aftaler & & & & & \\
\hline de studerende overholder mødetider og andre aftaler & & & & \\
\hline
\end{tabular}

Fig. 2: Spørgsmål om egen indsats fra Økonomisk Instituts standardevaluering

Det er unægtelig stadig subjektivt, hvad der er "rimeligt« eller "velbegrundet«. Men vil man evaluere kriteriebaseret, må Institut for Psykologis skema siges at være et modigt forsøg på at eksplicitere, hvad faget finder, er de generelle kriterier for god undervisning.

\section{Deltagerbaseret undervisningsevaluering}

En helt anden evalueringsmetode er udelukkende at bede de studerende om neutralt at beskrive deres oplevelser i undervisningen. Deltagerbaseret evaluering fortæller, hvordan deltageren havde det med eller rea- 
gerede på undervisningen, hvordan den foltes, om man vil. Og den begrænser ikke de svar, man kan fă, til de muligheder, evalueringsudformeren havde fantasi til at forestille sig.

Man beder altså de studerende med egne ord beskrive deres oplevelser - så subjektivt som muligt - for ad den vej få et dybere indblik i, hvordan læringen sker. Deltagerbaseret evaluering søger kun rådata, der ikke er klassificeret som noget godt eller noget skidt, da klassificeringen er det, der ville kræve ekspertise. Deltagerbaseret evaluering kommer således vores novice/ekspert-problematik fra kriteriebaseringen i møde Alle er kvalificerede til at evaluere deltagerbaseret.

Deltagerbaseret evaluering bliver nødvendigvis kvalitativ og består, hvis den skal være skriftlig, af prosa skrevet af de studerende. Derfor er denne evalueringsmetode måske af ressourcegrunde bedst egnet til mindre hold eller til at gennemføre med udvalgte dele af store grupper.

Metoden stiller antageligvis - endnu mere end andre metoder - krav til grundige tilbagemeldinger til de studerende, fordi deltagerbasering i høj grad kræver engagement fra de studerendes side, hvilket erfaringsmæssigt er svært at opnå, hvis ikke de studerende mærker, at deres evaluering bliver brugt til noget.

Alligevel er der noget at vinde ved denne form.

Hvis vi griber tilbage til, at studerende ikke nødvendigvis nyder god undervisning, fordi den største læring af og til opstår af frustration, kan vi forestille os en undervisning, hvor en pædagogisk bevidst underviser har valgt at provokere og frustrere sine studerende f.eks. for at opnå en grundlæggende aflæring, der kan give plads for en ny forståelse af fagets grundprincipper. Hvis disse studerende bliver bedt om at evaluere deres tilfredshed - måske endda kvantitativt - mens de stadig deltager i denne undervisning, vil de måske vurdere undervisningen negativt og give den "to" på en syvtrinskala (og "et« for indlæring, fordi de føler, de er blevet dummere). Hvis underviseren derimod făr et deltagerbaseret evalueringsmateriale, hvoraf det kan ses, hvor meget de studerende kæmper, og hvor hårdt og svært og frustrerende de finder faget, kan vores bevidste didaktiker i samarbejde med sine kolleger udlede, at det formål, han satte fra start, er opfyldt til fulde, og at hans undervisning er en succes - måske en »sekser " på syvtrinskalaen.

Det kan måske lyde som et upassende forslag, at evaluering ikke nødvendigvis skal værdisætte, når man betænker, at "evaluere ifølge Nudansk Ordbog (1999) betyder at "mene noget om kvaliteten af noget, f.eks. kvaliteten af et undervisningsforløb «. Men sagen er ikke, at der ikke skal vurderes kvalitet. Sagen er, at det skal være den professionelle underviser i det professionelle fagfællesskab med hans/hendes mere overordnede og kvalificerede forståelse af formålet med undervisningen, der skal gøre det; og det skal være underviseren i og med fagfællesskabet, der tager sine forbehold og laver sine ændringer udfra det mest interessante input, der i mange tilfælde kan udgøres af mere "rene« data om de studerendes oplevelse af og i undervisningen, der ikke først har været igennem en - ukvalificeret - værdisættelse fra de studerendes side.

For at betragte det foregående som et argument for deltagerbaseret evaluering skal man mene, at universitetets undervisere er professionelle undervisere, der er bedre kvalificeret end de studerende til at vurdere undervisnings kvalitet. Det er måske ikke pr. definition tilfældet. Mange undervisere har kun lidt eller slet ingen pædagogisk efteruddannelse. Det er i min optik en stor fejl, der bør rettes op på. Lige så klart, som det er, at man må uddanne de studerende til kritikere, hvis man vil bruge dem som kritikere, er det, at man må uddanne underviserne til at undervise og - som en delkompetence heraf - også til at evaluere, dvs. til at vurdere bl.a. egen undervisning udfra data om de studerendes oplevelser med denne.

Der hvor man har pædagogiske konsulenter eller evalueringsmedarbejdere ansat, kan disse naturligvis også inddrages i processen med at drage konklusioner og fremadrettede anbefalinger af deltagerbaseret evalueringsmateriale.

\section{Deltagerbaserede evalueringer på KU}

En ægte deltagerbaseret evaluering skulle kun spørge, hvordan de studerende oplever undervisningen - evt. hvordan de oplever bestemte aspekter eller øjeblikke, og søge rent beskrivende svar uden værdiladning.

Der er næsten ingen eksempler på denne form i mit materiale fra KU, selvom jeg selvfølgelig langt fra kan udelukke, at det forekommer på de fag, hvor underviserne selv designer deres studenterevaluering. De mange huller til kvalitative kommentarer i KU's evalueringer ønskes altid udfyldt med f.eks. "Andre gode ting ved undervisningen ", altså værdisatte kommentarer.

Angelo \& Cross (1993) har adskillige praktiske beskrivelser af, hvordan den enkelte underviser kan tilrettelægge, hvad jeg vil kalde deltagerbaserede evalueringer.

Man kan dog betragte det som et eksempel på deltagerbaseret evaluering, når undervisere på Økonomisk Institut bruger det, de kalder Harvard-metoden, hvor de efter udvalgte forelæsninger lader de studerende bruge nogle fă minutter på at skrive ned, hvad de mener, var hovedpointerne i forelæsningen. Disse skriverier får underviseren så. Det giver et direkte indblik $i$, hvordan de studerende har opfattet undervisningen, der kan være mere sigende end nok så mange syvtaller på en syv-trinsskala. Hvis f.eks. mange studerende beskriver et mere underordnet princip som hovedpointen, făr man som underviser en klar beskrivelse af, hvad der er sket, og et klart mål for udvikling af den pågxldende undervisning. 
Jeg har selv som studerende på Afdeling for Retorik været udsat for en deltagerbaseret evalueringsform, hvor skrivedidaktiklæreren holdt slutevaluering ved at bede os formulere en metafor for undervisningen, for underviserens rolle $\mathrm{i}$ den og for vores egen rolle på holdet. Metaforerne strakte sig fra "et symfoniorkester» til »en gruppe jægersoldater « - med underviseren som henholdsvis »dirigent" og "sergent . Tro det eller lad være, det kom der faktisk mange interessante diskussioner ud af, som kom tæt på kernen i de interpersonelle udvekslinger, der udgør undervisning.

På Det Teologiske Fakultet vælger underviserne selv formen på studenterevaluering, men der er et sæt retningslinjer for underviserens rapport til studienævnet om evalueringen. Det bliver ekstra væsentligt, hvis målet er at opnå ikke-dømmende tilbagemeldinger, at stille sine evalueringsspørgsmål så neutralt som muligt, og teologis retningslinjers meget lidt værdiladede formuleringer lægger op til, at man kunne lave deltagerbaseret evaluering.

I disse retningslinjer finder jeg særligt ordet "indtryk " i flere af spørgsmålene interessant. Der spørges f.eks. til "Indtryk af de studerendes forberedelsesgrad " - ikke hvor stor den er, eller hvor tilfreds underviseren er med den, men »indtrykket « af den. Det giver plads til at tænke $\mathrm{i}$ bredere baner, når man svarer. Man kunne f.eks. let forestille sig, at svaret på, hvordan de studerendes forberedelse har været, tit er, at det er meget differentieret eller individuelt, eller at de foretrækker at læse en bestemt type tekster. Det kan man svare, når man blot er spurgt om et »indtryk«. I samme oplæg bedes om: "Forslag eller bemærkninger af relevans for faggruppens undervisere - også meget neutralt formuleret. Der er ingen værdisættelse af "advarsler« eller "gode" ideer, som man ofte ser - men bare "forslag og bemærkninger".

Noget tyder på, at dette ikke-dømmende og udviklingsorienterede evalueringssystem er med til at give en god stemning omkring evaluering på fakultetet. I modsætning til mange, jeg har talt med, fra fag med mere kontrol- og tilfredshedsorienterede evalueringer udtalte studieleder på teologi Kirsten Busch Nielsen sig meget begejstret om lærernes tilbagemeldinger på undervisningsevalueringerne: »Det er en guldgrube af pædagogiske refleksioner".

\section{Andre evaluatorer}

Afslutningsvis vil jeg for det første minde om, at der findes mange slags studenterevalueringer foruden de rent skriftlige; dem har jeg desværre ikke haft plads til at kommentere, men det er yderst interessant.

For det andet er det ikke nogen naturlov, at det er de studerende, der skal være de primære evaluatorer af undervisning. Blooms (1956) kendte taksonomi sætter vurdering som det allerhøjeste læringsmål, det vil i taksonomisk sammenhæng sige, at for at kunne vurdere
- i dette tilfælde undervisning - skal man først kunne anvende og analysere. Man skal altså, hvis vi skal tage Bloom bogstaveligt, selv kunne undervise for at kunne evaluere undervisning. Så måske er kollegasupervision, team-teaching, eller hvad man nu kan finde på rundt omkring, der inddrager og styrker det faglige fællesskab blandt underviserne, et helt nødvendigt supplement for virkelig at evaluere på en måde, der kan udvikle underviserkompetencer ${ }^{8}$.

\section{Litteratur}

Angelo, Thomas A. \& Patricia Cross. (1993). Classroom Assessment Techniques, A Handbook for College Teachers. (2. udgave). San Francisco: Jossey-Bass.

Berliner, Peter \& Jens Bertelsen. (1989). »Passiv aggression - som voksenpædagogisk problem«. Nordisk Psykologi, nr. 41, s. 301315.

Bloom, Benjamin. S. (Ed.). (1956). Taxonomy of educational objectives. New York: David McKay.

Dahler-Larsen, Peter. (2004a). Evaluering af padagogisk efteruddannelse af universitetslarere. Center for Universitetspædagogik: Syddansk Universitet.

Dahler-Larsen, Peter. (2004b). Evaluering og Magt. Institut for statskundskab: Aarhus Universitet. (Magtudredningen).

Dahler-Larsen, Peter. (1997). "Orfeus' blik - om undervisningsevaluering $«$. Anne-Marie Mai, Jørgen Gleerup, Bent Ørsted og Peter Dahler-Larsen (red.): Imod en ny videnskabelig dannelse. Odense Universitet, s. 215-37.

Dreyfus, Hubert \& Stuart Dreyfus. (1999). „Mesterlære og eksperters læring«. Klaus Nielsen \& Steiner Kvale: Mesterlare. København: Hans Reitzel.

Elbow, Peter. (1981). Writing With Power. New York: Oxford University.

Herskin, Bjarne. (2001). Undervisningsteknik for universitetslarere. 2. udg. Samfundslitteratur.

Kellaghan, Thomas \& Daniel L. Stufflebeam. (2003). International Handbook of Educational Evaluation. Kluwer Academic Publishers.

Laursen, Per Fibæk. (1999). Didaktik og Kognition. Gyldendal.

Macdonald, Ranald \& James Wisdom. (2002). Academic and educational development. SEDA.

Müllen, Rikke von. (2005). Undervisningsevaluering som redskab til padagogisk udvikling på KU.

Olsen, Henning. (2001). Sprogforståelse og hukommelse i danske surveyundersøgelser. København: Socialforskningsinstituttet.

Politikens Nudansk Ordbog. (1999). Politikens Forlag.

Rienecker, Lotte \& Peter Stray Jørgensen. (1999). Opgaveskrivning på videregående uddannelser. Samfundslitteratur.

Rienecker, Lotte. (1996). "Feedback i grupper. Erfaringer og råd«. 2. udg. nr.1, Formidlingscentrets skrifter.

\section{Noter}

1 Se regeringens globaliseringsstrategi Fremgang, fornyelse og tryghed, kap. 7.7 (http://www.globalisering.dk/multimedia/Kap._ 7.pdf)

2 En samlet oversigt over forholdene på de fag, jeg undersøgte, findes på s. 21-23 i mit speciale, som er tilgængeligt på www. samf.ku.dk/pcs, under "tekster". De undersøgte evalueringsskemaer eller -systemer findes samme sted som bilag. Bemærk dog, at en del fag har ændret praksis de sidste to år.

3 Min inddeling af evaluering i kriteriebaseret og deltagerbaseret evaluering er stærkt inspireret af Elbow inddeling af kritiktyper (1981, kap.21). Rienecker (1996) bruger også Elbows dikotomi. 
4 Rienecker (1996, s. 16-17) peger på, at studerende ofte også er utilfredse med sig selv som kritikere. De kan godt mærke, hvis det ikke er et håndværk, de mestrer.

5 "Aflæring« og/eller "forforståelse« behandles i mange pædagogiske grundbøger, f.eks. Herskin (2001, bl.a. kap. 2) og Laursen (1999, kap. 9).

6 Dahler-Larsen (2004b, s. 33) giver flere eksempler på situationer, hvor tilfredshed og udbytte er omvendt korrelerede.

7 Olsen (2001, fra s. 131) giver eksempler på "genskabelsesfremmende procedurer».
8 Oliver \& Conole i Macdonald \& Wisdom (2002, s. 62-75) er én lang beskrivelse af det utroligt store udbytte, universitetsundervisere kan få af selv den simpleste dialogiske refleksion over egen undervisning sammen med kolleger. Dette tema har også været behandlet med samme varme anbefalinger i flere DUNsammenhænge, f.eks. i Jacqueline var Kruiningens (University of Groningen, Holland) oplæg på første dag af DUN-konferencen i 2004 . 